\title{
Pasienter som avbryter LAR-behandling - hvordan går det med dem?
}

\author{
BAKGRUNN Legemiddelassistert rehabilitering (LAR) er vanligvis en langvarig behandling. \\ En del LAR-pasienter avbryter behandlingen. Det er behov for mer kunnskap om hvordan \\ det går med disse.
}

MATERIALE OG METODE Vi gjorde en retrospektiv journalgjennomgang ved Sørlandet sykehus i Kristiansand av pasienter i LAR-behandling i perioden 1998-2009. Data fra 103 utskrevne pasienter er med i studien og ble registrert ved to tidspunkter - 31.12. 2009 og 30.6. 2011.

RESULTATER Av 469 pasienter som startet i LAR-behandling i perioden, avbrøt 103 pasienter (22\%) behandlingen. Halvparten av de 103 pasientene som var utskrevet, ble det fordi de selv ikke lenger ønsket LAR-behandling eller uteble. De andre var enten utskrevet med ønske om annen medisinering hos fastlege utenfor LAR $(n=11)$, fordi de oppfattet seg som rusfrie og ferdige med behandling $(n=19)$ eller fordi de fortsatt hadde et betydelig rusmiddelmisbruk ( $=21$ ). Det var sju pasienter som ønsket planlagt nedtrapping fra LAR-medisiner. Status for de 103 utskrevne pasientene pr 31.12. 2009 (median 1034 dager etter utskrivning): ukontrollert rusing: $30 \%$, døde: $17 \%$, annen medisinering hos fastlege: $14 \%$, psykiatrisk behandling: $12 \%$, fengsel: $8 \%$, LAR-behandling i andre fylker $2 \%$, rusfrie uten substitusjonsbehandling: $11 \%$, ukjent: $6 \%$. Etter ytterligere 18 måneder var status endret for 36 av dem. I gruppen ukontrollert rusing ( $n=31)$ i 2009 var endringen st $\varnothing r s t-14$ var tilbake i LAR-behandling, ti ruset seg fremdeles og fire var døde.

FORTOLKNING Det var høy dødelighet hos LAR-pasientene som avbrøt behandlingen. Om lag $10 \%$ av dem som ble utskrevet, levde stabilt rusfritt uten LAR-medisin i observasjonstiden.

Ved utgangen av 2012 var over 7000 pasienter i legemiddelassistert rehabilitering (LAR) i Norge (1). Det har vært en jevn økning i de senere år. Siden LAR-behandling ble introdusert som et nasjonalt tilbud for opioidavhengige i 1998, har mer enn 9000 pasienter vært med (2). En stor del av behandlingen utøves av fastleger i samarbeid med spesialisthelsetjenesten og sosialtjenesten (3).

Det er gjort en rekke evalueringer av pasientene gjennom årlige statusundersøkelser i perioden 2004-11 $(2,4)$. Hovedinntrykket fra undersøkelsene er at om lag to tredeler av dem som begynner i behandling, fortsetter i et langsiktig kontinuerlig perspektiv, mens omtrent en tredel avbryter behandlingen.

I tillegg til de årlige statusundersøkelsene er det gjennomført en rekke forskningsprosjekter der man har undersøkt resultatene av den norske LAR-behandlingen (5-8). Studiene viser at for utfall som død, kriminalitet og somatisk sykelighet reduseres forekomsten/risikoen til omtrent det halve mens pasientene er i LAR-behandling sammenliknet med tiden før slik behandling. Selv om vi vet en god del om nytten av LAR-behandling slik den praktiseres i den norske modellen, vet vi fortsatt lite om dem som av ulike grunner avslutter behandlingen.

I 2004 kom rusreformen, og med den fikk også pasientene i rusfeltet pasientrettigheter. Samtidig ble grunnlaget for tverrfaglig spesia- lisert rusbehandling lagt. Før 2004 kunne en pasient skrives ut fra LAR-programmet dersom vedkommende uteble, hadde en atferd preget av vedvarende rusing, omsatte LARmedikamenter, utøvet vold mot personell eller medpasienter eller jukset med urinprøvekontroller. Etter rusreformen, hvor skadereduksjon også ble en legitim målsetting $\mathrm{i}$ behandlingen, fikk «vedvarende rusing» mindre aktualitet som utskrivningsgrunn fra LAR-behandling. I dag er det $i$ henhold til de nye retningslinjene (9) og etablert kunnskap (10) helt unntaksvis at slik ufrivillig utskrivning finner sted.

Vår kliniske erfaring er at de fleste som avslutter behandlingen i dag gjør dette frivillig enten ved at de ber om utskrivning eller uteblir fra behandlingen. Funn basert på registerbaserte studier indikerer at utfall som kriminalitet og dødelighet forverres $\mathrm{i}$ «etter-LARperioden» for hele gruppen som avbryter behandlingen $(8,11,12)$. Vi vet imidlertid lite om hvorvidt de som avslutter er en homogen gruppe, om «etter-LAR-tilværelsen» er stabil eller om behandlingsstatus endres over tid.

Ifølge en rapport fra Seksjon for kliniske rusmiddelproblemer fra 2004 var $90 \%$ av de som var i LAR-behandling i sin første periode, mens ca. $10 \%$ hadde erfaring med flere behandlingsforsøk (13). Disse observasjonene er snart ti år gamle, og det har vært en utvikling i LAR-behandlingen i Norge.

I denne artikkelen beskrives kjennetegn og

\section{Thomas Clausen}

thomas.clausen@medisin.uio.no

Avdeling for rus og avhengighetsbehandling Sørlandet sykehus

og

Senter for Rus- og avhengighetsforskning (SERAF) Institutt for Klinisk medisin

Universitetet i Oslo

\section{Reidun Åsland}

Øistein Kristensen

Avdeling for rus og avhengighetsbehandling Sørlandet sykehus

Engelsk oversettelse på www.tidsskriftet.no

\section{HOVEDBUDSKAP}

En av fem av dem som startet LAR-behandling ved Sørlandet sykehus Kristiansand i perioden 1998-2009, avbrøt behandlingen

Majoriteten av dem som avbrøt behandlingen, levde i perioder med ukontrollert rusmiddelbruk og høy risiko for død 
behandlingsstatus for personer som avsluttet LAR-behandlingen ved Avdeling for Rus og avhengighetsbehandling ved Sørlandet sykehus.

\section{Materiale og metode}

Dette er en deskriptiv undersøkelse. Data ble innhentet $\mathrm{i}$ en retrospektiv journalgjennomgang ved Sørlandet sykehus. Høsten 2011 ble årlige statusrapporter og journalene til alle pasienter som var eller hadde vært $\mathrm{i}$ LAR-behandling i Vest-Agder fra oppstart høsten 1998 og til og med 2009 gjennomgått (469 pasienter) (fig 1). 103 var utskrevet per 31.12. 2009. Situasjonsstatus for disse ble registrert på to tidspunkter: $31.12 .2009 \mathrm{og}$ 30.6. 2011. Median observasjonstid mellom utskrivning og de to kontrolltidspunktene var 1034 dager per 31.12. 2009 og 1571 dager per 30.6. 2011.

Data, som ble registrert i et regneark, var alder, kjønn, dato for behandlingsstart, antall dager i behandling, type LAR-medikament, dato for eventuelle behandlingsavbrudd og årsak til behandlingsavbrudd samt journalinformasjon om dødsfall. Informasjon om situasjonsstatus ble hentet fra journalene og registrert ved de to tidspunktene 31.12. 2009 og 30.6. 2011 (en periode på 18 måneder). I noen få tilfeller var situasjonsstatus basert på lokalkunnskap hos behandlerne.

Kategoriene i figur 2 er gjensidig ekskluderende. Først ble det undersøkt om vedkommende var i ulike former for behandling/institusjon og ble da kategorisert i den aktuelle behandlingen. Det er mulig at en person er i behandling/fengsel og samtidig ruser seg, men da er vedkommende kategorisert som under behandling/institusjon. Det er kun de som ikke var i behandling eller i kjent institusjon og vi visste ruset seg som kom i «rusing»-kategorien.

Prosjektet ble lagt frem for vurdering for regional komité for medisinsk og helsefaglig forskningsetikk (REK) for Sør- og ØstNorge, som vurderte det til å ligge utenfor helseforskningslovens virkeområde og at det kunne gjennomføres uten godkjenning fra dem. Prosjektet er godkjent av Norsk samfunnsvitenskapelig datatjeneste (NSD). Det er benyttet deskriptiv statistikk med angivelse av median og gjennomsnitt med tilhørende spredningsmål. Alle data ble anonymisert.

\section{Resultater}

Kjennetegn ved hele LAR-kohorten

Det hadde vært totalt 469 pasienter i LAR-behandling i Vest-Agder i perioden 1998-2009. Per 31.12. 2009 var $323(69 \%)$ fortsatt $i$ LAR-behandling. 103 pasienter $(22 \%)$ var blitt utskrevet fra behandlingen (fig 1).

Av de 323 aktive LAR-pasientene var det $72 \%$ menn, og median alder ved oppstart av behandling var 35 år (spredning 21-62 år).

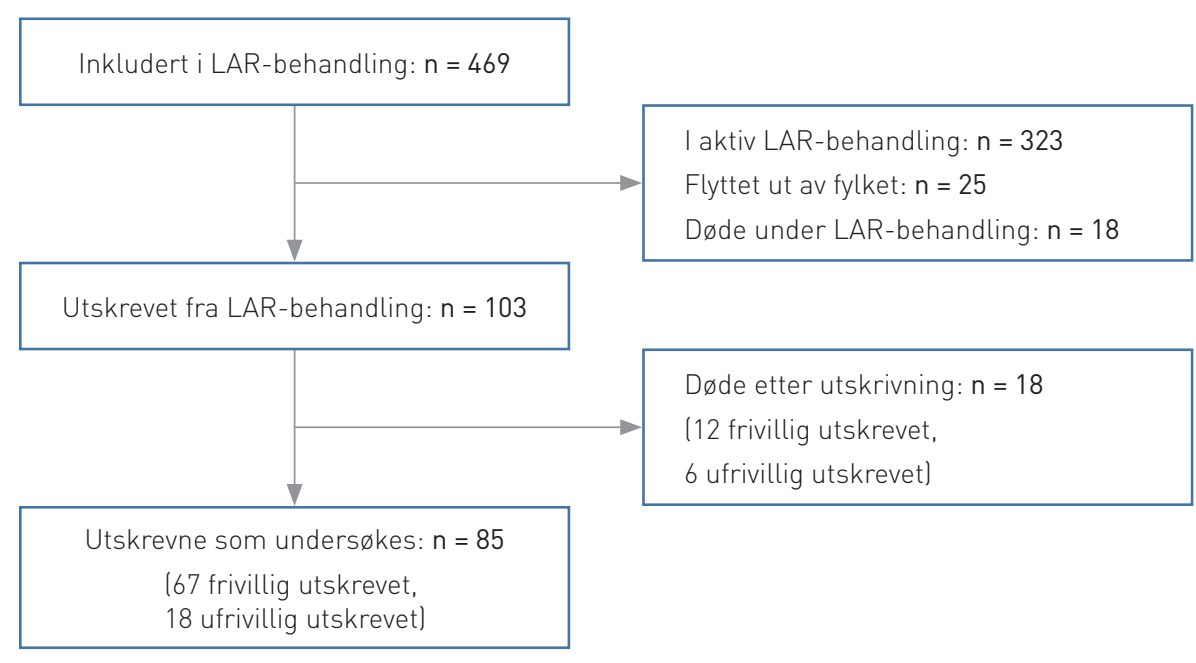

Figur 1 Pasienter i legemiddelassistert rehabilitering ved Sørlandet sykehus i perioden 1998-31.12. 2009
Median tid i behandling var 1463 dager (spredning 15-4 144 dager) (tab 1). Av LARpasienter i behandling oppga $99(30 \%)$ at de ikke hadde ruset seg det siste året (i 2009).

\section{Kjennetegn ved 103 pasienter} utskrevet fra LAR-behandling

De som var utskrevet, hadde sammenliknbar alders- og kjønnsfordeling som pasientene $\mathrm{i}$ behandling, men de hadde kortere gjennom- snittlig opphold i LAR-behandling (435 dager versus 1601 dager) (tab 1). Av de 103 pasientene som var utskrevet hadde $28 \%$ mer enn én LAR-behandlingsperiode bak seg per 31.12. 2009.

\section{Årsaker til avbrutt behandling}

Av dem som var utskrevet fra LAR per 31.12. 2009, var halvparten $(\mathrm{n}=52)$ utskreog utskrivning

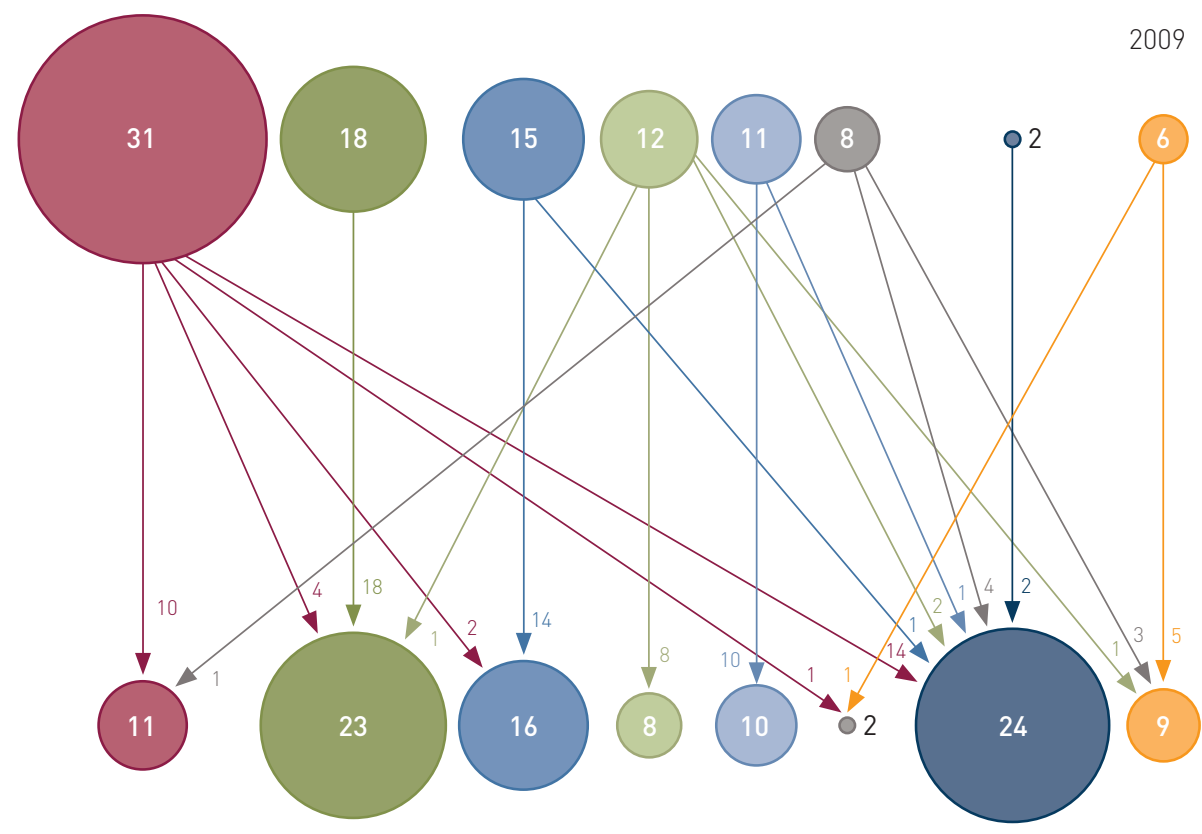

$\square$ Rusing $\square$ Døde $\square$ Fastlege utenfor LAR

$\square$ Psykiatrisk behandling $\square$ Rusfri $\square$ Fengsel $\square$ LAR $\square$ Ukjent

Figur 2 Behandlingsstatus for pasienter utskrevet fra legemiddelassistert rehabilitering (LAR) ( $n=103$ ) ved Sørlandet sykehus i 31.12. 2009 og 30.6.2011. Endringer mellom 2009 og 2011 er vist med piler og tall. Kategoriseringen tar først utgangspunkt i aktuell behandling. De som ikke var i behandling eller i kjent institusjon og der det forelå informasjon om «rusing», kom i denne kategorien 
Tabell 1 Kjennetegn ved pasientene som var i legemiddelassistert rehabilitering (LAR) ved Sørlandet sykehus og de som var utskrevet fra LAR per 31.12. 2009

\begin{tabular}{lcc} 
Kjennetegn & Pasienter i LAR & Utskrevet fra LAR \\
Antall & 323 & 103 \\
Alder (år) ved behandlingsstart, median (spredning) & 35,0 (21-62) & $35,6(22-51)$ \\
Antall dager i behandling 1. episode, median (spredning) & $1463(15-4144)$ & 435 (6-3 800) \\
Andel menn (\%) & 72 & 69 \\
Andel metadon (\%) & - & 26 \\
Andel buprenorfin (\%) & - & 21 \\
Andel brukt både metadon og buprenorfin (\%) & - & 28 \\
Andel frivillig utskrevet (\%) & - & 27 \\
Andel som senere restartet LAR (\%) & & 26 \\
\hline
\end{tabular}

vet enten fordi de selv ikke ønsket å fortsette behandlingen eller de uteble fra behandlingen (autoseponerte). De øvrige årsakene (gjensidig utelukkende kategorier) for utskrivning var at pasientene enten oppfattet seg som rusfrie og ferdige med behandlingen $(n=19)$ eller ønsket annen medisinsk behandling hos fastlege $(n=11)$ (f.eks. vedlikeholdsbehandling hos fastlege utenfor LAR) eller hadde falt tilbake til betydelig rusmiddelbruk $(\mathrm{n}=21)$.

$23 \%$ var definert som ufrivillig utskrevet (fig 1). Andelen ufrivillig utskrevne før og etter rusreformen 1.1. 2004 var henholdsvis $44 \%$ og $8 \%$.

21 personer var utskrevet på grunn av rusmiddelbruk, hvorav 16 var skrevet ut før rusreformen i 2004. 15 var skrevet ut ufrivillig. Etter rusreformen var fem personer skrevet ut på grunn av rusbruk, hvorav fire ufrivillig.

\section{Status for utskrevne}

31.12. 2009 og 30.6. 2011

Av de 103 utskrevne per 31.12. 2009 var 18 døde. For de gjenlevende 85 fant vi opplysninger om 79 (fig 2).

I 2009 var det 31 som ruset seg ukontrollert og åtte som satt i fengsel - det vil si at 39 av 79 var utenfor ordinær rusbehandling. 29 var $\mathrm{i}$ en eller annen form for medisinsk behandling (rus eller psykiatri). 11 personer ble beskrevet som rusfrie, og sju av disse hadde sluttet med rusmidler etter planlagt nedtrapping av LAR-medisiner.

Ved observasjon 18 måneder senere (30.6. 2011) fant man endring i situasjonsstatus hos 36 av de utskrevne gjenlevende personene fra 2009 (fig 2). Færre ruset seg på det tidspunktet ukontrollert $(\mathrm{n}=11)$, mens flere var $i$ vedlikeholdsbehandling $i$ LAR eller hos fastlege $(n=40)$. Den største gruppen som hadde endret situasjonsstatus hadde gått fra ukontrollert rusing i 2009 og tilbake i LAR-behandling $(\mathrm{n}=14)$, mens en tredel av dem som ruset seg ukontrollert $\mathrm{i}$ 2009, hadde samme status i 2011. Det var stor stabilitet i gruppene som var i medisinsk behandling hos fastlege og for dem som levde rusfritt. Ti av de 11 fra 2009 levde fortsatt rusfritt i 2011.

Ytterligere fem personer var døde i løpet av 18 måneder. Av alle de 23 som var døde etter utskrivning fra LAR-behandling, beskrives 13 av tilfellene som overdosedødsfall. Dødeligheten i perioden 31.12. 2009-30.6. 2011 for de utskrevne personene med kjente opplysninger i 2011 var fire dødsfall per 100 personår.

\section{Diskusjon}

De som avbrøt LAR-behandlingen i vår studie, var en heterogen gruppe, og utskrivningsgrunnene varierte. Dødeligheten var høy. Etter avslutning i LAR var det nokså stor ustabilitet når det gjaldt situasjonsstatus, men mange vendte tilbake til perioder med vedlikeholdsbehandling.

Undersøkelsen vår viste at for $77 \%$ av dem som ble utskrevet fra LAR i løpet av observasjonsperioden, skjedde dette frivillig. Innføringen av rusreformen i 2004 markerte et tydelig skille. Før 2004 var andelen med ufrivillig utskrivning $44 \%$, etter 2004 falt denne til $8 \%$.

Av de overlevende pasientene som var utskrevet, var nær halvparten tilbake i vedlikeholdsbehandling i juni 2011, enten i form av LAR-behandling eller annen substitusjonsmedisinering fra fastlege. Nær halvparten pendlet således mellom å være i og utenfor LAR-behandling.

I vårt materiale var omtrent én av ti som være rusfri eller i medikamentfri behandling hadde avsluttet LAR-behandling vurdert å i juni 2011. Dette tyder på at noen få LARpasienter kan klare seg godt uten substitusjonsbehandling over tid. De som klarer å oppnå en langvarig rusfri tilværelse etter LAR-behandling, er kjennetegnet av avsluttet rusmiddelbruk, ønsket og planlagt nedtrapping og nettverk med rusfrie venner/ familie (14).

Dødeligheten hos ubehandlede opioidavhengige er høy. I internasjonale studier er den anslått å ligge mellom $2 \%$ og $4 \%$ per år $(15,16)$. I Norge ble det funnet en dødelighet på $2,4 \%$ per år hos dem som sto på venteliste for LAR-behandling og en dødelighet på $1,4 \%$ per år for dem som var i behandling (5).

I denne studien var dødeligheten for dem som hadde avsluttet LAR-behandling 4\% per år i perioden 2009-11. De fleste dødsfallene rammet gruppen som ble beskrevet å ha rusatferd i 2009. Avsluttet LAR-behandling og fortsatt rusatferd utenfor LAR ser ut til å være en kombinasjon som gir høy dødsrisiko. Den observerte dødeligheten er litt høyere enn tidligere dokumentert nasjonalt estimat for dødelighet etter LAR-behandling (3,4\% per år), basert på tallmateriale fra 1998-2003 (5). Mer enn 50\% overdoser som dødsårsak etter avbrutt behandling, som observert i denne studien, samsvarer med nasjonalt estimat (12).

I en svensk undersøkelse med 38 pasienter som hadde vært i stabil metadonbehandling i over ti år, fant man at de som ble utskrevet fra behandlingen ufrivillig, hadde dårligere utvikling enn de som trappet ned frivillig - det gjaldt både rusbruk og opplevd livskvalitet (14). 13 pasienter forsøkte å trappe ned metadonbehandlingen frivillig $\mathrm{i}$ løpet av 15 år. Sju gjennomførte en vellykket nedtrapping og levde angivelig et opiatfritt liv (14). De fleste av disse hadde ordnede familiære og sosiale forhold da de avsluttet LAR-behandlingen. Andelen rusfrie pasienter fra Vest-Agder var ca. $10 \%$, noe lavere enn i den svenske studien, men samlet tyder disse studiene på at kun en liten andel av dem som avslutter LAR-behandling, klarer å leve rusfritt på lengre sikt.

Kjennetegn ved dem som klarte å leve rusfritt uten LAR-medikasjon var, ut fra den svenske studien, at de hadde vært mange år i stabil LAR-behandling, hadde etablert rusfrie nettverk og selv ønsket nedtrapping (14). Kun én av ti som avsluttet LARbehandling i Vest-Agder levde et rusfritt liv, mot én av tre av dem som ble værende i LAR siste år. Dette er i tråd med en Cochraneoppsummering, som viser nytte av LAR sammenliknet med ingen behandling når det gjelder rusmestring (17).

Gruppen som uteble fra LAR-behandlingen $(\mathrm{n}=28)$ var stor. Av de døde $(\mathrm{n}=23)$ utgjorde disse ikke-planlagte og pasientinitierte utskrivningene hele $39 \%$. Av dem 
som overlevde var en stor andel tilbake enten LAR-behandling eller i medisinering hos fastlege ved observasjon medio 2011.

I en fersk studie fra Norge er det vist at kriminalitet som uttrykk for negativ atferd $i$ behandlingen økte gradvis de siste $100 \mathrm{da}-$ gene før behandlingsavbrudd (18). Det er derfor viktig at klinikere er oppmerksomme på negative utviklingstrekk, som for eksempel økende rusmiddelbruk og problematferd som kriminalitet, og setter inn ekstra tiltak slik at behandlingsavbrudd kan forebygges. Vi mener det er viktig å etablere rutiner for raskest mulig å kunne gi tilbud om ny behandling og dermed redusert dødsrisiko for dem som avbryter behandlingen. Tilsvarende vil det være aktuelt å vurdere både om doseringen av LAR-medisiner er adekvat eller om man kan oppnå bedre effekt av behandlingen ved å skifte til et annet medikament (19).

Ettersom LAR er en behandlingsform som bygger på samarbeid mellom spesialisthelsetjenesten, sosialtjenesten og fastlegen, er det viktig at alle parter er oppmerksomme på risikoen som kan være forbundet med å avbryte behandlingen og jobber sammen mot målet: å beholde pasientene i behandlingen. Vår oppfatning er derfor at det er noe urovekkende at nær én av fire fastleger ikke er positive til LAR eller ikke har erfaring med å forskrive LAR-medisiner (3). Selv om hovedmålet i LAR er retensjon i behandlingen og rehabilitering, bør det også være en åpning for at en liten gruppe - de langvarig stabilt rusfrie LAR-pasientene med støttende rammer rundt seg - i samarbeid med behandlerne kan forsøke nedtrapping dersom de selv ønsker det.

\section{Evalueringens styrker og svakheter}

Denne undersøkelsen av en samlet kohort av LAR-pasienter fra perioden 1998-2009 muliggjør et helhetlig overblikk og en systematisk oppsummering av behandlingsresultatene ved avdelingen ut fra en gjennomgang av alle journalene. En retrospektiv journalgjennomgang som denne vil imidlertid bare fange opp opplysninger som klinikerne er blitt kjent med og som er blitt journalført i sykehusets journal. Dette kan gi en tendens til større oppmerksomhet rundt «negative» hendelser som har ført til kontakt med sykehuset, sammenliknet med de tilfellene der pasienten lever et liv uten behov for fornyet kontakt med avdelingen.

Estimatene for død, fengsling og psykiatrisk behandling vil være konservative, ettersom det ikke er gjort registerundersøkelser eller annen verifisering av opplysningene utover journalgjennomgangen fra LAR-avdelingen i Vest-Agder.
Det er sannsynlig at de som avslutter LAR-behandling, er en gruppe med ekstra utfordringer knyttet til rusmiddelbruk og komorbiditet sammenliknet med de som blir i behandlingen over tid. I denne studien har vi ingen konkrete mål på denne eventuelle seleksjonseffekten.

Pasientkjennetegn og funn fra Vest-Agder reflekterer i stor grad de nasjonale resultatene som rapporteres $i$ årlige statusrapporter og fra nasjonale registerbaserte studier. Beskrivelsene fra denne studien vurderes derfor å gi et godt estimat på utskrivningsårsaker og situasjonsstatus etter LAR-behandling i mange andre regioner i Norge.

\section{Lærdommer for videre klinisk praksis}

Denne studien tyder på at gruppen som avbryter LAR-behandling, er dominert av personer som fortsatt har perioder med ukontrollert rusmiddelbruk og høy risiko for død.

Selv om majoriteten av dem som starter LAR-behandling blir i behandlingen lenge, er det en betydelig andel som ikke finner seg til rette. Det bør derfor gjøres undersøkelser av mulige faktorer ved behandlingstilbudet som kan bidra til å senke frafallet.

En stor andel av dem som avslutter LARbehandling, kommer senere tilbake og gjør nye forsøk i LAR eller med annen form for vedlikeholdsbehandling. Et tett samarbeid med fastlegene vil derfor være viktig for oppfølging av denne gruppen. Det bør legges til rette for at overgangene mellom ulike behandlingsperioder eller behandlingsformer gjøres $i$ et helhetlig pasientforløpsperspektiv.

Pasienter som avslutter LAR-behandling, bør ha lett tilgjengelighet til reinntak uten unødvendig forsinkende prosedyrer, slik at risikoen for komplikasjoner og død reduseres.

\section{Thomas Clausen (f. 1972)}

er professor dr.med. ved SERAF, Universitetet iOslo

Forfatter har fylt ut ICMJE-skjemaet og oppgir ingen interessekonflikter.

\section{Reidun Åsland (f. 1956)}

er psykiatrisk sykepleier og enhetsleder ved poliklinikken for rusbehandling.

Forfatter har fylt ut ICMJE-skjemaet og oppgir ingen interessekonflikter.

\section{Øistein Kristensen (f. 1945)}

er spesialist i psykiatri, overlege og forsker. Han har 15 års erfaring med LAR-behandling Forfatter har fylt ut ICMJE-skjemaet og oppgir ingen interessekonflikter.
Litteratur

. Waal H, Bussesund K, Clausen T et al. Statusrapport 2012: LAR som det vil blifremover? Oslo: SERAF, Universitetet i Oslo, 2013.

2. Waal H, Clausen $T$, Håseth A et al. Statusrapport 2011 - LAR i helseforetakene. Oslo: SERAF, Universitetet Oslo, 2012.

3. Waal H, Brekke M, Clausen T et al. Fastlegers syn på legemiddelassistert rehabilitering. Tidsskr Nor Legeforen 2012; 132: 1861-6.

4. Hansen MB, Kornør H, Waal H. Statusrapport for pasienter i legemiddelassistert rehabilitering 2002-2003. Oslo: SKR, Universitetet i Oslo, 2004.

5. Clausen T, Anchersen K, Waal H. Mortality prior to during and after opioid maintenance treatment (OMT): a national prospective cross-registry study. Drug Alcohol Depend 2008; 94: 151-7.

6. Anchersen K, Clausen T, Gossop M et al. Prevalence and clinical relevance of corrected $Q T$ interval prolongation during methadone and buprenor phine treatment: a mortality assessment study. Addiction 2009; 104: 993-9.

7. Skeie I, Brekke M, Gossop M et al. Changes in somatic disease incidents during opioid maintenance treatment: results from a Norwegian cohort study. BMJ Open 2011: 1: e000130.

8. Bukten A, Skurtveit S, Gossop M et al. Engagement with opioid maintenance treatment and reductions in crime: a longitudinal national cohort study. Addiction 2012: 107: 393-9.

9. Helsedirektoratet. Nasjonal retningslinje for legemiddelassistert rehabilitering ved opioidavhengighet. Oslo: Helsebiblioteket, 2010. www.helsebiblioteket.no/Retningslinjer/LAR/ Forord (3.5.2013)

10. Kornør H, Waal H. From opioid maintenance to abstinence: a literature review. Drug Alcohol Rev 2005; 24: 267-74.

11. Skeie I, Brekke M, Clausen T et al. Increased somatic morbidity in the first year after leaving opioid maintenance treatment: results from a norwegian cohort study. Eur Addict Res 2013; 19: 194-201.

12. Clausen $T$, Waal $H$, Thoresen M et al. Mortality among opiate users: opioid maintenance therapy, age and causes of death. Addiction 2009; 104 $1356-62$

13. Moen S, Hansen MB, Waal H. Legemiddelassistert rehabilitering - en livslang behandling? Oslo: SKR, Universitetet i Oslo, 2004

14. Hiltunen AJ, Eklund C, Borg S. The first 38 methadone maintenance treatment patients in Stockholm: 15-year follow-up with a main focus on detoxification from methadone. Nord J Psychiatry 2011: 65: 106-11.

15. Degenhardt L, Bucello C, Mathers B et al. Mortality among regular or dependent users of heroin and other opioids: a systematic review and metaanalysis of cohort studies. Addiction 2011; 106: $32-51$

16. Jimenez-Treviño L, Saiz PA, García-Portilla MP et al. A 25-year follow-up of patients admitted to methadone treatment for the first time: mortality and gender differences. Addict Behav 2011: 36 : $1184-90$

17. Mattick RP, Breen C, Kimber J et al. Methadone maintenance therapy versus no opioid replacement therapy for opioid dependence. Cochrane Database Syst Rev 2009; nr. 3: CD002209.

18. Bukten A, Røislien J, Skurtveit $S$ et al. A day-byday investigation of changes in criminal convic tions before and after entering and leaving opioid maintenance treatment: a national cohort study. BMC Psychiatry 2013; 13: 262

19. Hser YI, Saxon AJ, Huang D et al. Treatment retention among patients randomized to buprenorphine/naloxone compared to methadone in a multi-site trial. Addiction 2014; 109: 79-87.

Mottatt 21.6. 2013, første revisjon innsendt 11.10. 2013, godkjent 25.3. 2014. Redaktør: Trine B. Haugen. 